\title{
Faktor-Faktor Yang Mempengaruhi Indeks Pembangunan Manusia Di Kabupaten Pidie Tahun 2010 - 2017
}

\author{
Lena Marleni *a, Khairil Anwar *b \\ *Fakultas Ekonomi dan Bisnis Universitas Malikussaleh \\ a Corresponding author: lenimarleniekp@gmail.com \\ b khairil.anwar.semsi@gmail.com
}

A T I C LE INF ORMATION A A T R C

\section{Kata Kunci:}

Gross Regional Domestic Product, Poverty, Labor, Human Development Index
This study aims to analyze determination of the Human Development Index in Pidie Regency in 2010-2017. This study are secondary data from 2010 to 2017. This study utilizes the multiple linear regression. The results of the study partially showed that the Gross Regional Domestic Product and the Number of labors had a positive and significant effect on the Human Development Index in Pidie Regency from 2010 to 2017. Poverty has a negative and significant effect on the Human Development Index in Pidie Regency from 2010 to 2017. Simultaneously, GDP, poverty and the number of labors had a positive and significant effect on the Human Development Index in Pidie Regency from 2010 to 2017

\section{PENDAHULUAN}

Indek Pembangunan Manusia menunjukkan tingkat keberhasilan manusia dalam suatu daerah. Indek pembangunan manusia dipengaruhi oleh beberapa faktor seperti produk. domestik regional bruto, Kemiskinan dan tenaga kerja. Adapun perkembangan Indek Pembangunan Manusia Kabupaten Pidie yaitu sebagai berikut :

\section{Tabel 1}

\section{PDRB, Kemiskinan , Tenaga Kerja dan IPM}

\section{Kabupaten Pidie}

\begin{tabular}{|l|l|l|l|l|}
\hline Tahun & $\begin{array}{l}\text { PDRB Atas Dasar } \\
\text { Harga Konstan } \\
\text { (Milyar) }\end{array}$ & $\begin{array}{l}\text { Kemiskin } \\
\text { an (000) } \\
\text { Jiwa }\end{array}$ & $\begin{array}{l}\text { Tenaga Kerja } \\
\text { (Jiwa) }\end{array}$ & $\begin{array}{l}\text { IPM } \\
(\%)\end{array}$ \\
\hline 2010 & $5.329 .053,77$ & 87,000 & 12,521 & 68.38 \\
\hline 2011 & $5.729 .225,87$ & 84,090 & 11,620 & 68.69 \\
\hline 2012 & $6.191 .450,28$ & 84,320 & 13,287 & 68.9 \\
\hline 2013 & $6.723 .034,52$ & 90,120 & 11,209 & 69.26 \\
\hline 2014 & $7.254 .638,18$ & 93,230 & 12,011 & 67.87 \\
\hline 2015 & $7.862 .077,33$ & 99,660 & 12,312 & 68.68 \\
\hline 2016 & $8.509 .987,55$ & 88,220 & 13,471 & 69.06 \\
\hline 2017 & $8.614 .497,76$ & 70,160 & 12,292 & 70.01 \\
\hline
\end{tabular}

Sumber : BPS Pidie, 2018
PDRB merupakan salah satu faktor yang mempengaruhi indek pembangunan manusia. Berdasarkan tabel 1 menunjukkan bahwa PDRB di Kabupaten Pidie berfluktuasi selama Tahun 2010 sampai 2017. PadaTahun 2014 PDRB mengalami peningkatan akan tetapi IPM justru menurun. Hal ini tentu tidak sesuai dengan teori dimana secara teori apabila PDRB meningkat maka IPM akan meningkat karena apabila PDRB dalam suatu daerah tinggi maka belanja modal juga akan semakin meningkat sehingga akan berdampak pada meningkatnya Indek Pembangunan Manusia, (Sukirno, 2010).

Jika garis kemiskinan semakin meningkat dan manusia tidak mampu memenuhi kebutuhan dasar mereka maka akan rendahnya pendapatan nyata sehingga akan mengakibatkan permintaan menjadi rendah sehingga investasi juga rendah dan dapat mengurangi produktivitas.

Berdasarkan tabel 1 menunjukkan bahwa kemiskinan di Kabupaten Pidie berfluktuasi 
selama Tahun 2010 sampai 2017. PadaTahun 2013 kemiskinan mengalami peningkatan akan tetapi IPM justru ikut meningkat. Hal ini tentu tidak sesuai dengan teori dimana secara teori apabila kemiskinan meningkat maka IPM akan menurun (Sukirno, 2010).

Selain dari pada PDRB dan kemiskinan, jumlah tenaga kerja juga menjadi salah satu faktor yang mempengaruhi indek pembangunan Manusia.

Berdasarka tabel 1 di atas menunjukkan bahwa terjadinya fluktuasi jumlah tenaga kerja selama tahun 2010-2017. Pada Tahun 2011 jumlah tenaga kerja menurun dan indek pembangunan manusia justru meningkat. Hal ini tidak sejalan dengan teori yang menyatakan bahwa semakin tinggi jumlah tenaga kerja maka akan semakin tinggi pula IPM dalam suatu daerah.

Penelitian ini bertujuan untuk melihat pengaruh PDB, tingkat kemiskinan dan jumlah tenaga kerja terhadap indeks pembangunan manusia.

Tulisan ini akan membahas tinjauan teoritis pada bagian kedua, pada bagian ketiga akan memaparkan metode penelitian, hasil pembahasan dapat dilihatdi bagian ke empat, dan akhirnya kesimpulan dan saran di bagian ke lima.

\section{TINJAUAN TEORITIS}

\section{Indek Pembangunan Manusia}

Suatu daerah yang sedang berkembang membutuhkan sejumlah manusia yang berkualitas dan mempunyai daya saing nasional dan international. Baik buruknya kualitas manusia dalam suatu daerah dapat dilihat dari indek pembangunan manusia yang mencerminkan tingkat keberhasilan manusia dalam daerah tersebut.

Berdasarkan pendapat di atas maka dapat disimpulkan bahwa indesk pembangunan manusia merupakan kualitas dari masyarakat dalam suatu wilayah dalam menjalani kehidupan untuk memperoleh sejumlah pendapatan, pendidikan dan kesehatan.

\section{Kerangka Konseptual}

Adapun kerangka konseptual dalam penelitian ini adalah:

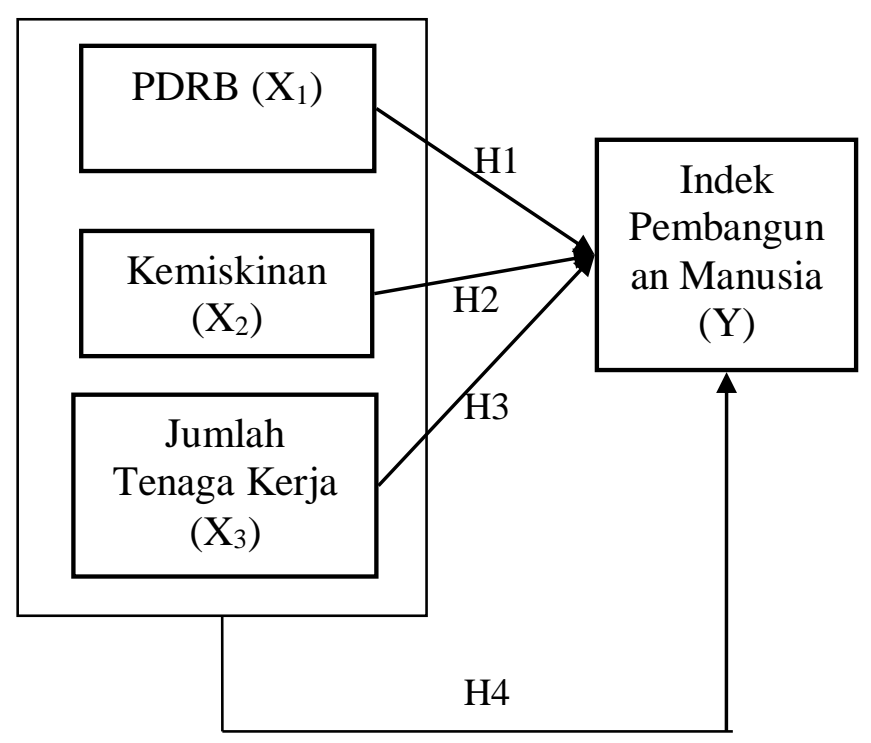

\section{Gambar 1 Kerangka Konseptual}

\section{METODE PENELITIAN}

\section{Data dan Sumber Data}

Jenis data dalam penelitian ini menggunakan data time series dari variabel PDRB, kemiskinan dan jumlah tenaga kerja serta indeks pembangunan manusia dari tahun 20102017 yang diperoleh dari BPS Indonesia.

\section{Metode Analisis Data}

Metode analisis data dalam penelitian ini adalalh penelitian yang bersifat kuantitatif. Menurut Sugiyono, (2003) Penelitian kuantitatif, adalalh penelitian dengan menggunakan program 
eviews memperoleh data yang berbentuk angka atau data kualitatif yang diangkakan. Adapun model analisis dalam penelitian ini adalalh:

$$
\mathrm{Y}=\mathrm{a}+\mathrm{b}_{1} \log \mathrm{X}_{1}+\mathrm{b}_{2} \log \mathrm{X}_{2}+\mathrm{b}_{3} \log \mathrm{X}_{3}+\mathrm{e}
$$

Dimana:

$$
\begin{array}{ll}
\mathrm{Y} & =\text { Indek Pembangunan Manusia } \\
\mathrm{a} & =\text { Konstanta }
\end{array}
$$

$b_{1}, b_{2}, b_{3}=$ Koefisien Regresi

$\mathrm{X}_{1} \quad=$ Produk. Domestik Regional Bruto (PDRB)

$$
\begin{array}{ll}
\mathrm{X}_{2} & =\text { Kemiskinan } \\
\mathrm{X}_{3} & =\text { Jumlah Tenaga Kerja }
\end{array}
$$

\section{Uji Normaitas}

normalitas bertujuan untuk menguji apakah dalam model regresi variabel dependen dan variabel independen keduanya mempunyai distribusi normal atau tidak. Model regresi yang baik adalah memiliki distribusi normal atau mendekati normal. Untuk mendeteksi apakah residualnya berdistribusi normal atau tidak dengan membandingkan nilai Jarque Bera dengan $\chi^{2}$ (chisuquare) tabel, yaitu sebagai berikut :

a. Jika nilai Prob $\mathrm{Jb}<5 \%$, maka residualnya berdistribusi tidak normal.

b. Jika nilai Prob $\mathrm{Jb}>5 \%$, maka residualnya berdistribusi normal.

\section{Uji Asumsi Klasik}

\section{Uji Multikolinieritas}

Uji multikolinieritas adalah situasi adanya korelasi variabel-variabel bebas diantara satu dengan yang lain. Uji multikolinearitas adalah salah satu pengujian di dalam asumsi klasik yang berguna untuk melihat apakah variabel-variabel indepeden di dalam penelitian memiliki hubungan atau tidak. (Gujarati, 2012) mengatakan bahwa model regresi linear berganda yang baik tidak memiliki hubungan di antara variabel-variabel bebasnya. Uji multikolinieritas dapat dilihat melalui nilai $\mathrm{r}$ korelasi. Tidak terjadi multikolinieritas apabila nilai $\mathrm{r}$ korelasi di dibawah 0,8 .

\section{Uji Autokorelasi}

Menurut Gujarati (2012) keputusan pengambilan autokorelasi yaitu :

a. Apabila nilai Obs*R-Square $<X^{2}$ (chi-square) maka tidak terjadi autokorelasi.

b. Apabila nilai Obs*R-Square $>X^{2}$ (chi-square) maka tidak terjadi autokorelasi.

Selanjutnya hasil uji autokorelasi juga dapat di lihat dengan membandingkan probabilitas ChiSquared dan nilai signifikan $5 \%$ yaitu sebagai berikut :

a. Apabila nilai Prob Chi-Squared $<5 \%$, maka terjadi autokorelasi.

b. Apabila nilai Prob Chi-Squared > 5\%, maka tidak terjadi autokorelasi.

\section{Uji Heteroskedastisitas}

Uji heteroskedastisitas bertujuan untuk menguji apakah dalam model regresi terjadi ketidaksamaan variance dari residual satu pengamatan ke pengamatan lain. Menurut (Widarjono, 2013) Keputusan terjadi atau tidaknya heteroskedastisitas pada model regresi linier dapat dilihat melalui chi Square hitung $\left(\mathrm{X}^{2}\right)$ lebih kecil dari chi squared $\left(X^{2}\right)$ tabel pada tingkat $\alpha=5 \%$..

Untuk mendeteksi ada tidaknya heteroskedastisita maka dengan membandingkan nilai R-squared dan tabel chi-square.

a. Jika nilai Obs*R-squared > chi-square tabel, maka tidak lolos dari uji heteroskedastisitas. 
b. Jika nilai Obs*R-squared < chi-square tabel, maka lolos dari uji heteroskedastisitas.

\section{Pengujian Hipotesis}

Setelah dilakukan pengukuran variable dalam penelitian ini, maka dilakukan pengujian hipotesis. Untuk melakukan keputusan menerima atau menolak hipotesis yang diajukan, maka perlu dilakukan pengujian secara statistik.

\section{Uji t}

Uji t dilakukan untuk melihat pengaruh variabel independen terhadap variabel dependen secara parsial. Bila $t_{\text {hitung }}>\mathrm{t}_{\text {tabel }}$ dengan tingkat signifikan 5\%, dan jika $t_{\text {hitung }}<\mathrm{t}_{\text {tabel }}$ dengan tingkat signifikan 5\%, maka dapat disimpulkan bahwa variabel independen tidak berpengaruh terhadap variabel dependen.

\section{Uji F (simultan)}

Pengujian ini bertujuan untuk mengetahui pengaruh variabel independen secara bersamasama terhadap variabel dependen dengan melihat nilai signifikansi F. Bila $f_{\text {hitung }}>f_{\text {tabel }}$ dengan tingkat signifikan 5\%, maka dapat disimpulkan bahwa secara simultan variabel independen berpengaruh signifikan terhadap variabel dependen.

\section{HASIL PENELITIAN DAN PEMBAHASAN}

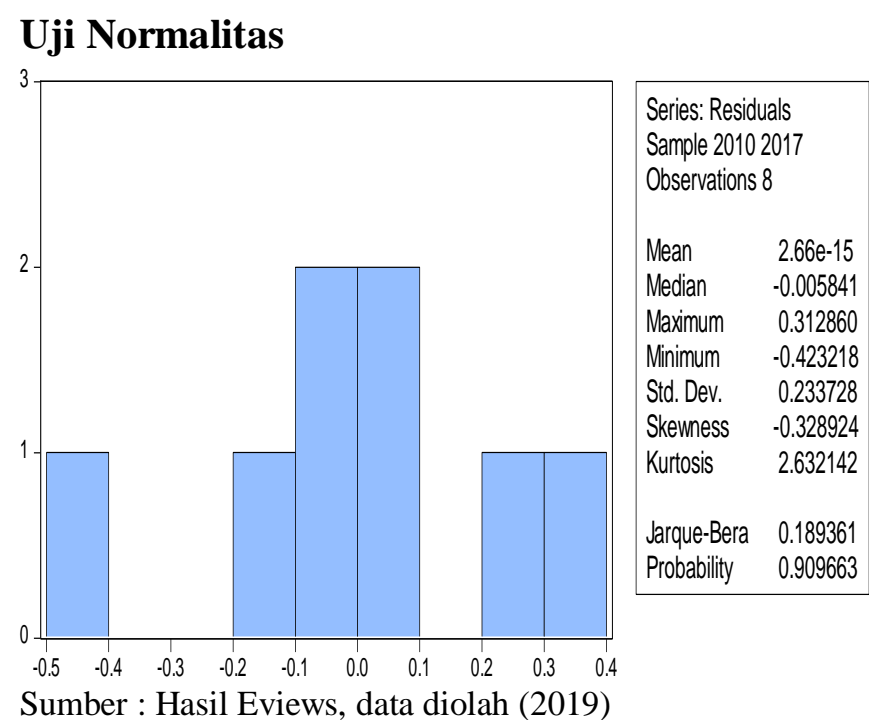

Gambar 2

Hasil Uji Normalitas

Berdasarkan hasil uji normalitas menunjukkan bahwa nilai JB sebesar 0,189 $<$ 7,81 sehingga dapat disimpulkan bahwa data terdistribusi normal, dan hasil dari uji normalitas menunjukkan bahwa nilai Prob JB > 0,05 yaitu sebesar 0,909> 0,05 maka dapat disimpulkan bahwa residual berdistribusi normal. Apabila hasil penelitian secara normalitas menunjukkan data terdistribusi secara normal maka penelitian ini layak untuk dilakukan dan dilanjutkan dengan pengujian yang lainnya.

\section{Uji Asumsi Klasik \\ Uji Multikolinieritas}

Tabel 2

Hasil Uji Multikolinieritas

\begin{tabular}{|l|r|r|r|}
\hline & $\begin{array}{c}\text { Coefficient } \\
\text { Variance }\end{array}$ & $\begin{array}{c}\text { Uncentered } \\
\text { VIF }\end{array}$ & $\begin{array}{c}\text { Centered } \\
\text { VIF }\end{array}$ \\
\hline L & 286.0688 & 23938.73 & NA \\
\hline LOG(PDRB) & 0.319425 & 6604.721 & 1.687015 \\
\hline LOG(TK) & 1.430830 & 15481.02 & 1.092675 \\
\hline
\end{tabular}

Sumber : Hasil eviews, 2019

Hasil uji multikolinieritas dapat dilihat pada tabel 2 di atas yang menunjukkan bahwa 
model ini terbebas dari masalah multikolinieritas dimana nilai centered VIF dari variabel PDRB, Kemiskinan dan Tenaga Kerja masing masing berada di bawah 10 .

\section{Uji Autokorelasi}

\section{Tabel 3}

Uji Autokorelasi

Breusch-Godfrey Serial Correlation LM Test:

\begin{tabular}{llll}
\hline \hline F-statistic & 1.940608 & $\begin{array}{l}\text { Prob. (2,2) } \\
\text { Prob. Chi- } \\
\text { Obquare(2) }\end{array}$ & 0.3401 \\
\hline \hline
\end{tabular}

Sumber : Data diolah (2019)

Berdasarkan hasil out put $\mathrm{Obs} * \mathrm{R}$-squared sebesar 5,27 di bandingkan dengan Chi-Squared tabel pada df (3) sebesar 7,81, maka 5,27 $<7,81$ berarti data muncul sudah berbeda sehingga tidak terjadi autokorelasi serta nilai Prob Chi-Squared sebesar 0,071 >0,05. Berdasarkan hasil tersebut maka dapat disimpulkan bahwa dalam penelitian ini tidak terjadi autokorelasi atau tidak terdapat kesalahan pengganggu yang muncul antar tahun selama periode 2010 sampai 2017.

\section{Uji Heteroskedastisitas}

\section{Tabel 4}

\section{Uji Heteroskedastisitas}

Heteroskedasticity Test: White

\begin{tabular}{llll}
\hline \hline F-statistic & 0.257731 & Prob. F(3,4) & 0.8529 \\
Obs*R-squared & 1.295891 & Prob. Chi-Square(3) & 0.7301 \\
Scaled explained & & & \\
SS & 0.782650 & Prob. Chi-Square(3) & 0.8536 \\
\hline \hline
\end{tabular}

Sumber : Data diolah, (2019)

Dari hasi tabel 4 di atas dapat dilihat bahwa nilai obs* R-square untuk hasil estimasi uji Glejser adalalh sebesar 1,29 dan nilai $X^{2}$ tabel dengan derajat kepercayaan $5 \%$ dan df (3) adalalh 7,81 karena nilai Obs*R-squared 1,29 $<$ 7,81 maka dapat disimpulkan bahwa model diatas lolos dari heteroskedastisitas. Hal ini juga dapat dilihat dari probabilitas Chi-Squared sebesar 0,730, nilai tersebut $0,730>0,05$.

\section{Analisis Regresi Linier Beerganda \\ Tabel 5}

Hasil Analisis Regresi Linier Berganda

\begin{tabular}{lcccc}
\hline \hline Variable & Coefficient & Std. Error & t-Statistic & Prob. \\
\hline \hline C & 49.30108 & 16.91357 & 2.9148830 .0435 \\
LOG $\left(X_{1}\right)$ & 2.083390 & 0.565177 & 3.6862630 .0211 \\
LOG $\left(X_{2}\right)$ & -3.479291 & 1.196173 & -2.9086850 .0437 \\
LOG $\left(X_{3}\right)$ & 2.793217 & 0.735763 & 3.7963540 .0192 \\
\hline \hline & 0.962659 & Mean dependent var & 68.60625 \\
R-squared & 0.934653 & S.D. dependent var & 1.209533 \\
Adjusted R-squared & 0.309193 & Akaike info criterion & 0.797151 \\
S.E. of regression & 0.382401 & Schwarz criterion & 0.836871 \\
Sum squared resid & 0.811397 & Hannan-Quinn criter. & 0.529250 \\
Log likelihood & 34.37362 & Durbin-Watson stat & 2.349365 \\
F-statistic & 0.002582 & & \\
Prob(F-statistic) & \multicolumn{5}{c}{} \\
\hline \hline
\end{tabular}

Sumber : Eviews 8, data diolah (2019)

Dari tabel 5 di atas maka model regresi linier berganda adalalh sebagai berikut :

$\mathrm{Y}=49.30108+2,083390 \log \mathrm{X}_{1}-3,479291$

$\log X_{2}+2,793217 \log X_{3}$

Dari hasil di atas dapat di interpretasi hasil analisis regresi linier berganda yaitu sebagai berikut :

1. Constanta sebesar 49.30108 menunjukkan apabila variabel PDRB, kemiskinan dan tenaga kerja tidak bertambah maka variabel dependen indek pembangunan manusia mempunyai nilai sebesar $49.30108 \%$.

2. Koefisien variabel Produk. Domestik Regional Bruto mempunyai nilai sebesar 2,083390, Hal ini menunjukkan hubungan yang positif. Artinya apabila produk. domestik regional bruto mengalami peningkatan $1 \%$ maka Indek Pembangunan Manusia akan mengalami peningkatan sebesar 2,083390 \%. Sebaliknya apabila Produk. domestik regional bruto 
mengalami penurunan $1 \%$ maka indek pembangunan manusia akan mengalami penurunan sebesar $2,083390 \%$.

3. Koefisien variabel Kemiskinan mempunyai nilai sebesar - 3,479291, Hal ini menunjukkan hubungan yang negatif. Artinya apabila kemiskinan mengalami peningkatan $1 \%$ maka Indek Pembangunan Manusia akan mengalami penurunan sebesar 3,479291 \%. Sebaliknya apabila kemiskinan mengalami penurunan $1 \%$ maka indek pembangunan manusia akan mengalami peningkatan sebesar 3,479291\%.

4. Koefisien variabel tenaga kerja mempunyai nilai sebesar 2,793217, Hal ini menunjukkan hubungan yang positif. Artinya apabila jumlah tenaga kerja mengalami peningkatan $1 \%$ maka Indek Pembangunan Manusia akan mengalami peningkatan sebesar 2,793217\%. Sebaliknya apabila jumlah tenaga kerja mengalami penurunan $1 \%$ maka indek pembangunan manusia akan mengalami penurunan sebesar $2,793217 \%$.

\section{Pengujian Parsial}

Adapun hasil pengujian hipotesis di dalam penelitian ini adalalh sebagai berikut:

1. Secara parsial Produk. Domestik Regional Bruto berpengaruh terhadap Indek Pembangunan Manusia di Kabupaten Pidie Periode 2010 sampai 2017. Hal ini ditunjukkan oleh hasil nilai $\mathrm{t}$ hitung $>\mathrm{t}$ tabel yakni 3,686 > 2,131 dan nilai signifikan sebesar $0.021<0.05$. Dengan demikian maka dapat disimpukan maka Hipotesis pertama dalam penelitian diterima.

2. Secara parsial Kemiskinan berpengaruh terhadap Indek Pembangunan Manusia di Kabupaten Pidie Periode 2010 sampai 2017.
Hal ini ditunjukkan oleh hasil nilai $\mathrm{t}$ hitung $>\mathrm{t}$ tabel yakni 2,908> 2,131 dan nilai signifikan sebesar $0.043<0.05$. Dengan demikian maka dapat disimpukan maka Hipotesis kedua dalam penelitian diterima.

3. Secara parsial Jumlah Tenaga Kerja berpengaruh terhadap Indek Pembangunan Manusia di Kabupaten Pidie Periode 2010 sampai 2017. Hal ini ditunjukkan oleh hasil nilai $\mathrm{t}_{\text {hitung }}>\mathrm{t}$ tabel yakni 3,796 > 2,131 dan nilai signifikan sebesar $0.019<0.05$. Dengan demikian maka dapat disimpukan maka Hipotesis ketiga dalam penelitian diterima.

\section{Pengujian Simultan}

Hasil penelitian menunjukkan bahwa secara simultan PDRB, kemiskinan dan jumlah tenaga kerja berpengaruh terhadap Indek Pembangunan Manusia hal ini dibuktikan dengan uji statistik $\mathrm{F}_{\text {hitung }}>\mathrm{F}_{\text {tabel }}$ yaitu $34,373>6,591$ dan nilai signifikan sebesar $0.002<0.05$.

\section{Pembahasan}

\section{Pengaruh Pengaruh Produk Domestik Regional} Bruto terhadap Indek Pembangunan Manusia.

Hasil dari penelitian ini menunjukkan bahwa secara parsial Produk. Domestik Regional Bruto berpengaruh terhadap Indek Pembangunan Manusia di Kabupaten Pidie Periode 2010 sampai 2017. Hal ini ditunjukkan oleh hasil nilai $\mathrm{t}_{\text {hitung }}>\mathrm{t}$ tabel yakni 3,686>2,131 dan nilai signifikan sebesar $0.021<0.05$.

Hasil penelitian ini menunjukkan bahwa apabila produk. domestik regional bruto meningkat maka indek pembangunan manusia juga akan meningkat. Hal ini sejalan dengan pendapat Khodabakhshi (2011) menemukan 
bahwa PDB memiliki pengaruh positif terhadap IPM. Pertumbuhan ekonomi yang baik ditunjukkan oleh kenaikan PDB dalam skala nasional dan PDRB skala regional/ daerah setiap tahunnya. Kenaikan pertumbuhan ekonomi hendaknya diiringi oleh pembangunan manusia di dalamnya.

\section{Pengaruh Kemiskinan terhadap Indek Pembangunan Manusia.}

Hasil dari penelitian ini menunjukkan bahwa secara parsial kemiskinan berpengaruh terhadap Indek Pembangunan Manusia di Kabupaten Pidie Periode 2010 sampai 2017. Hal ini ditunjukkan oleh hasil nilai $\mathrm{t}$ hitung $>\mathrm{t}$ tabel yakni 2,908 > 2,131 dan nilai signifikan sebesar $0.043<0.05$. Hasil penelitian ini menunjukkan bahwa apabila kemiskinan terjadi peningkatan maka indek pembangunan manusia akan semakin rendah.

\section{Pengaruh Jumlah Tenaga Kerja terhadap Indek Pembangunan Manusia.}

Hasil dari penelitian ini menunjukkan bahwa secara parsial jumlah tenaga kerja berpengaruh terhadap Indek Pembangunan Manusia di Kabupaten Pidie Periode 2010 sampai 2017. Hal ini ditunjukkan oleh hasil nilai $\mathrm{t}_{\text {hitung }}>\mathrm{t}$ tabel yakni 2,796 > 2,131 dan nilai signifikan sebesar $0.019<$ 0.05. Hasil penelitian ini menunjukkan bahwa apabila jumlah tenaga kerja terjadi peningkatan maka indek pembangunan manusia akan semakin tinggi.

Ketika produk. tivitas tenaga kerja meningkat maka hal tersebut dapat mempengaruhi daya jualnya dalam arti upah yang akan diterima bertambah. Hal tersebut membuat perusahaan mencari cara untuk mengurangi biaya dengan mengurangi inputnya dan menggantikannya dengan hal lain yang lebih murah seperti halnya teknologi.

Semakin tinggi pendidikan seseorang akan berpengaruh terhadap kesempatan mereka mendapatkan pendapatan yang lebih baik. Hal ini mendorong penerima kerja lebih mencari tenaga kerja yang pendidikan lebih tinggi guna mendorong produk. tivitasnya, sehingga dalam hal ini pencari pekerja akan mengurangi jumlah pekerja yang tidak produk. tif. Hal ini berdampak pada berkurangnya tingkat partisipasi angkatan kerja yang disebabkan sebagian besar angakatan kerja Indonesia bisa dikatakan memiliki skill rendah.

\section{KESIMPULAN DAN SARAN}

\section{Kesimpulan}

Berdasarkan hasil penelitian dan pembahasan, maka peneliti mengemukakan kesimpulan sebagai berikut :

1. Secara parsial Produk. Domestik Regional Bruto berpengaruh positif dan signifikan terhadap Indek Pembangunan Manusia di Kabupaten Pidie Periode 2010 sampai 2017.

2. Secara parsial Kemiskinan berpengaruh negatif dan signifikan terhadap Indek Pembangunan Manusia di Kabupaten Pidie Periode 2010 sampai 2017.

3. Secara parsial Jumlah Tenaga Kerja berpengaruh positif dan signifikan terhadap Indek Pembangunan Manusia di Kabupaten Pidie Periode 2010 sampai 2017.

4. Secara simultan PDRB, kemiskinan dan jumlah tenaga kerja berpengaruh positif dan signifikan terhadap Indek Pembangunan Manusia di Kabupaten Pidie Periode 2010 sampai 2017. 


\section{Saran}

Adapun saran yang dapat diberikan peneliti dalam penelitian ini adalalh sebagai berikut :

1. Bagi pemerintah daerah, diharapkan dalam peningkatan IPM melalui pengentasan kemiskinan untuk periode tahun dengan lebih menekankan pada penciptaan lapangan pekerjaan yang lebih memadai.

2. Untuk itu disarankan kepada pemerintah daerah untuk meningkatkan pendapatan masyarakat yanga ada di Kabupaten Pidie melalui sektorsektor yang banyak menyerap tenaga kerja seperti sektor padat karya sehingga bisa meningkatkan pendaptan penduduk yang digunakan untuk kebutuhan seharai-hari dan kebutuhan pendidikan keluarga mereka.

3. Bagi pemerintah diharapkan memperhatikan masalah yang berhubungan dengan pengurangan kemiskinan dengan peningkatan produk. tivitas masyarakat melalui investasi di bidang pendidikan dan kesehatan agar Indek Pembangunan Manusia dapat lebih ditingkatkan

\section{DAFTAR PUSTAKA}

Afrida , BR. (2008), Ekonomi Sumber Daya Manusia, Ghalia Indonesia:Jakarta

Cahyat, Ade, (2004), Bagaimana Kemiskinan di Ukur:Beberapa Model Penghitungan Kemiskinan di Indonesia, Center for Internation al Forestry Research (CIFOR), Bogor.

Jhingan, M, (2007), Ekonomi Pembangunan dan Perencanaan, Raja Grafindo Persada: Jakarta.

Moekijat, (2007), Manajemen Tenaga Kerja, Pionir Jaya: Bandung.

Prasetyo, Bambang, (2010), Metode Penelitian Kuantitatif: Teori dan Aplikasi. Rajawali Pers, Jakarta.
Ranupandojo, Heidjrachman (2006), Manajemen Personalia, BPFE UGM, Yogyakarta.

Sadulloh, Uyoh, (2006), Pengantar Filsafat Pendidikan, Alfebata: Bandung.

Sugiyono. (2009). Metode Penelitian Kuantitatif dan Kualitatif. CV. Alfabeta:Bandung.

Sumarsono, Sonny, (2009), Ekonomi Sumber Daya Manusia Teori dan Kebijakan Publik. Graha Ilmu: Jogyakarta.

Suryawati, C (2005), Memahami Kemiskinan secara Multidimensional. JMPK Vol. 08/No.03/September/2005.

Wibisono, Yusuf (2010). Metode Statistika. Gadjah Mada University Press: Yogyakarta.

Widodo, Tri, (2006), Perencanaan Pembangunan, UPP STIM YKPN : Yogyakarta. 